Sign Systems Studies 30.1, 2002

\title{
Back to the science of life
}

\author{
Anton Markoš, Fatima Cvrčková \\ Department of Philosophy and History of Sciences, Charles University, \\ Viničná 7, Prague 2, 12800 Czechia \\ e-mail:markos@cts.cuni.cz
}

\begin{abstract}
We give a survey of epistemological and ontological approaches that have left traces in the 20th-century biology. A common motive of most of them is the effort to incorporate biology into the realm of physical sciences. However, such attempts failed, and must fail in the future, unless the criterion for what science is becomes biologically oriented. This means broadening the realm of classical natural sciences, incorporating at least part of the thesaurus of the "humanities". We suggest three mutually complementary candidates for further development in this direction: modular biology, the hermeneutics of the living, and the semiotic disciplines.
\end{abstract}

In the bitterness of their victory over their clerical opponents, [the biologists] have made the meaninglessness of the universe into a new dogma.

Dyson (1979: 249-250)

Recently, we have witnessed a number of strange terminological shifts, where the subject of particular science becomes confounded with the science itself. Thus psychology means both mental phenomena and the science studying them, a piece of fine organic chemistry was needed when life originated on the planet, and the same holds for, say, physiology, ecology, botany, or even biology as such. But observing that a plant is growing is not biology yet, nor speaking about one's feelings and thoughts is psychology. The scope of a 
special science is always more limited than its subject. Life is not only biology, mind is not the same as psychology.

This does not mean that special sciences deal simply with a mere subset of traits characteristic for their subject. An established science, if creative, will also create new phenomena appropriate for the current set of paradigms held at the time. Monoclonal antibodies, inbred clones of mice, or a single species of protein in a test tube are constructs of a special science - biology. Such constructs, and models based thereon, may provide extremely efficient tools, models and maps, enabling description and understanding of certain aspects of reality. However, any model — scientific or otherwise - is no more and no less than a caricature of the real world, and we should remain aware of the limits of its validity. Paradoxes and inconsistencies between a model and observation may indicate either a principal fault, or a mere transgression of the limits of model applicability. As Sidney Brenner (1997: 36) noted, Occam's razor should always be accompanied by Occam's broom - to sweep the cut bits under the carpet. A substantial part of model formulation concerns defining the borders of the carpet - i.e. the part of world where our models make sense.

Within the realm of natural sciences, biology has always held a strange position. Not all features of the living could be forced to meet the stringent measures of "hard" science, as exemplified by classical physics. It is not because spontaneity, evolution of complex systems, historicity, or even meaning were absent from the non-living realm. It is because during the last three centuries, modern science had chosen to ignore such appearances as mere epiphenomena of "real", objective, fully knowable causal laws acting in the background. For biology, however, the task to meet such criteria was even harder than for other experimental sciences: evolution and ontogeny always tended to escape any general rules. Here we shall try to show how various schools of biological thought try to negotiate the paradox.

Besides such "physicalist" attempts, there always existed a respectable tradition of philosophical thinking that pinned down those properties of the lived world (Lebenswelt) which resist "collapsing" into the schemes of physical sciences and "biology" derived thereof. In this article we shall treat briefly some of the numerous 20th-century attempts to found biology in a way which would respect specificity of the living realm, yet take advantage of the methodological armoury of 
"hard" sciences. All such attempts represent different ways of projecting the teeming realm of the living onto a kind of map, or better grid or matrix, containing limited number of dimensions and therefore methodically manageable. The examples chosen are mostly balancing on the edge between turning life into physics, or jumping out of the physical world altogether. This "living on the edge" is, of course, inherent to the very realm of life (Kauffman 1993). However, depending on the factors taken into account, it can project into substantially different conceptions of the "science of life". All of them necessarily carry a burden of some sort of bias. Depending on what axes were selected for the projection, we obtain different models of life, often incompatible, at least to some respects, with other models. As an alternative, we give in the second part a short survey of biosemiotics, as we understand it. In the third part we attempt to formulate outlines of another two "grids" which we consider to be best fitted, at present, for understanding the realm of the living, namely modular biology and hermeneutics of the living (undoubtedly charged with their own biases).

\section{Physicalism}

We use this somewhat ugly term to encompass all the worldviews based on the conviction that all natural phenomena are subject to eternal, immutable laws. In biology, there have existed several great schools of physicalism, differing in how they were able to treat the historical dimension of life. We will proceed from mechanicism and its branch through biological structuralism, vitalism and organicism, to biology as understood by two contemporary authors: Mae-Wan Ho and Stuart A. Kauffman. We will discuss the extent to which the explanatory scheme of these branches relies to objective existence of immutable, once-for-all given laws (objective in the sense "existing out there", not merely "agreed by peers"), compared to free exploration and invention within the space of meanings. 


\section{Anton Markoš, Fatima Cvrčková}

\section{Mechanicism}

A mechanism is a projection of the world into the geometrical space. Making use of a device - mechanical or not - means understanding causal interdependencies of its parts, i.e. being in principle able to characterize them by a set of (simple) mathematical equations. It should be stressed that mechanical functioning could never be reconciled with historicity, introduced by evolution. The clockwork functioning of the world was the leading idea in natural sciences up to the end of the 19th century. This ethos began to crumble with the onset of modern physics and mathematics. Moreover, hand by hand with mechanism always goes the question after its creator.

Owing to trifles of history, the mainstream biology has remained the stronghold of mechanicism long into the 20th century. This, surprisingly, persists despite the fact that biologists fully acknowledge evolution as the principal formative force shaping the realm of the living. The uneasy compromise was helped by extreme reductionism ending in atomism, both chemical (molecular behaviour) and conceptual (contemporary evolutionary genetics). It is true, the argument goes, that at the macroscopic level we observe intentionality, free will, historicity and the like, but all these are nothing but epiphenomena safely grounded in the mechanical behaviour of molecules - i.e. something fully predictable from the initial and boundary conditions. Yet chance may enter at this level, be it genuine chance, measure of our ignorance, or some tricks implemented from the quantum world. If we, however, succeed to set such appearances, which are felt as disturbances, aside, or if we succeed to suppress them experimentally, we should end up essentially with predictable, truly objectively accessible world. All phenomena at the macroscopic scale of both space and time can be explained as causal consequences of either elementary mechanical movements, or genetic instructions read and executed blindly by mechanical protein contraptions.

Contemporary mechanistic thought in biology is characterised by two pillars: (1) molecular biology as taught by Jacques Monod (1979), and (2) sociobiology epitomized by the name of Edward O. Wilson (1998). Yet even in such strongholds of mechanicist thinking we can follow a strange - albeit rarely reflected — shift away from hard science and towards semiotics. Monod introduced the concept of gratuity, which, by all measures, cannot be acknowledged as 
belonging to chemistry. It is rather a description how molecules become symbols. The nature of molecules as chemical entities suddenly plays only a marginal role: they serve as a mere medium to store or deliver meaning. Sociobiology, in turn, gave birth to memetics, which parts even with the last bonds of the causal molecular world and becomes a free game of symbols (Dawkins 1989; Blackmoore 2000). By these and similar moves even the mainstream of biology may have transgressed its own horizon long ago.

\section{Biological structuralism}

Structures, the central concept of (biological) structuralism, can again be viewed as a kind of reduction - projection - collapse of the multi-dimensional space onto a construct. This time it is not the $3 \mathrm{D}$ Cartesian space of the mechanicists. Instead of invariant molecules and kinetic laws, invariance is supplied by implementations of structures into the lived world (see, e.g., Webster, Goodwin 1996). Evolution and morphogenesis is viewed as a result of lawful (i.e. in principle, as in the previous case, fully knowable) transformations of ever-existing and unchangeable structure. The structure is a system of relationships that always has existed, and its transformation proceeds according to fixed rules (although this does not mean that transformations themselves are given in advance - only the rules are conservative, not the outcomes). Knowledge of rules of (trans)formation allows one to analyse the order of formations of things, and the principal task is to find these rules.

Structuralism also stresses the relationship between the whole and its parts: a thing is to be understood not as a single fact or term, but as a totality, and only as such it has any meaning. Its parts gain their meaning only from their position in the whole structure. If we succeed in deciphering the nature of the relationships between the parts and the whole, we get a model of a given structure. Such a model will become a formal analogue of all models organized by that structure; thus it makes it possible to unify even domains which, at first sight, have nothing in common (for example various mathematical theories). In science, the structuralist approach is an attempt to overcome - or better, complement or correct - explanations based on the reduction 


\section{Anton Markoš, Fatima Cvrčková}

to the molecular level. Each level of description becomes the basic level with its own structural laws.

It is important to realize that the system of transformations - in the structuralists' interpretation, is closed; it develops and becomes enriched because of inherent rules that are independent of outside influences. At the same time it does not allow the structure to transgress the limits pre-set by rules. Novelties may appear only if they have always been virtually present as potentials of the structure. Historical events, i.e. trajectories of the system in time, cannot change the rules - otherwise no structured space would exist, but only a kind of eternal flow akin to the Heracleitan River. From a postulate of the self-sufficiency of a structure it follows that a structure can be totally known in itself, without any need to refer to elements outside the structure.

In a closer view, the very notion of virtual presence brings about problems. "Virtual presence" is not objective: the structure is a mere point in the space of possibilities. This space is teeming with possibilities, also mutually exclusive ones, in a kind of superposition. Structuralists tend to stress that any decision, selection or interpretation results in a collapse from this space into a single solution, thus revealing a preexisting attractor. But we might ask whether the system of transformations could not be open, endlessly creating new possibilities - and new structures.

Structuralism, as physics and as molecular biology, is seeking what is timeless, fixed, and constant: the grammar and the vocabulary of a given language or of a given phenotype. Evolution and morphogenesis become a system of fixed and lawful (i.e. objectively decipherable) transformations where no contingency is allowed. We end with a kind of rational morphology supported by mathematics.

The aim is thus similar to that of physicalism. However, in contrast to mechanicism, structuralism has no ambition to reduce biology to physics. Biological phenomena stay in their own "causal domain" (Havel 1996), without reference to other domains of description. Physics is attractive because it supplies examples (analogies) how to build a rational taxonomy without any need for history. To disclose such an order for the realm of living beings should be - according to structuralism - the principal goal of all biologists. Hence, biology should break away from the flaws of historicity and finally transform itself into a true science worth of physicalists' criteria. 


\section{Vitalism and organicism}

The vitalists' endeavour (here we present mainly views held by one of its main protagonists among the biologists, Hans Driesch (1905, 1914, 1929)) was also to encompass the phenomenon of life into the body of physical science. Vitalism is a conviction that life processes are autonomous, i.e. understandable only in the context of the living, not from some "simpler" levels, such as that of chemistry. But these autonomous processes, themselves, are also governed by a fully describable principle(s). Life, as a property of a living body, is in no way the result of physico-chemical events, but rather a ruler of those. This, however, does not mean that spontaneity or even free will should be allowed for.

The vitalists therefore felt a need to find and define principles controlling vital processes; they always stressed that such principles should be expressed as measurable variables, being in simple mathematical relations to magnitudes already known. Thus, the priority was, again, to discover simple laws that govern life, i.e. to broaden the realm of physics to be able to embed life more completely into it. This quest can best be demonstrated by their rejection of Darwinian theory: they held that introducing historical contingencies into pure science was unacceptable!

Driesch, as one of the pioneers of experimental embryology and discoverer of regulatory processes in early embryos, centres his efforts on the explanation of regeneration. To understand such phenomena, one has to presume the existence of harmony (causal, structural or functional) and purposiveness in organisms. His aim was to prove this assumption.

When in the 1920s it became obvious that vitalism had become depleted of explanatory potential and dogmatic, i.e. of no practical use in experimental science, the term organicism was coined instead in the 1930s (Bertalanffy 1960). Its aim, again, was to explain the obvious fact of emergent properties of complex systems, encountered on the way from a "lower" level of description to a "higher" one. This tamed form of vitalism survived in developmental biology for the rest of the century and, according to Gilbert and Sarkar (2000) will also have much to say in the century coming.

Perhaps it will, but we do not see much difference between the organicist statement "Different laws are appropriate for each level of 


\section{Anton Markoš, Fatima Cvrčková}

description", and the vitalist "There are life-specific laws". In our opinion, the controversy - often very heated - between mechanicism, vitalism and organicism could perhaps have been resolved on a purely terminological ground. Not much will change if we, instead of proposing "autonomous laws of the living realm", speak of expanding physics and chemistry in order to accommodate life, pointing to generally accepted instances of such previous expansions, such as the whole area of organic chemistry. Moreover organicist statements can also easily be applied to any complex dissipative system, which means that they do not provide the answer to the basic question: "What is the difference between the living and the nonliving?" Is our understanding sharper if we speak of information, complexity, or structure without having clear idea of the meaning of such words?

The anxiety not to leave the Cartesian world "where the laws of chemistry and (Newtonian) physics rule" is, in our opinion, condemned to failure. If biology, psychology and similar areas of human knowledge are to become sciences with a status similar to physics, they ought to abandon their vain attempt to confine biology into the Cartesian space and do what physics did several decades ago: transcend it.

\section{"Enlightened physicalism" of M.-W. Ho: Introducing the concepts of quantum physics}

One possibility how to do this may be encompassing, at last, the 20th century developments in physics. Quantum physics has turned the traditional question after material structures upside down and started to ask after the structure of matter, opening thereby perspectives unavailable to classical physics. Surprisingly, few biologists took this challenge seriously. Mae-Wan Ho in her earlier works (see, for example 1993, 1994) makes a serious attempt to describe living beings in terms of self-structuring fields. Inspired by the Fröhlich theory of resonance (see, for example, Pokorný 1995), she sees living beings as coherent systems synchronized through many levels of organization.

According to Ho, organisms can be characterised by high-efficiency energy transfers with minimum losses. She interprets this fact 
as evidence that energy transformations in living beings are of a different order from those described by standard chemical kinetics. The latter are defined for reactions in homogenous space involving very high numbers of molecules, and characterized by quantities based on the averaging of states of large numbers of particles (temperature, concentration, free energy, entropy, etc.). Such quantities, however, cannot be defined for the interior of living cells - they have no meaning there, because the space within the cell is highly structured. Evidence for the presence of elaborate - almost crystal-like — order within living things is seen in the observation that live cells, unlike dead ones, exhibit optical polarization. This means that cells do not contain anything like homogeneous solutions (see also Hess, Mikhailov 1995, 1996, or any current textbook, for support of this notion; compare also the concept of evolution based on non-ergodicity in Kauffman 2000).

In such a highly ordered space, huge numbers of molecules (of the order of $10^{20}$ ) interact in a coherent (i.e. coordinated, nonlocal) manner, ensuring extreme efficiency of energy transfers. Ho assumes that the coherence present in organisms is quantum in nature, and interprets living beings as highly coherent systems, interconnected through many spatial $\left(10^{-10}-10^{1} \mathrm{~m}\right)$ and temporal $\left(10^{-14}-10^{7} \mathrm{~s}\right)$ orders. Although she is far from providing conclusive evidence for the involvement of quantum phenomena, we believe that her introduction of quantum physics concepts into biology represents a hopeful way of transcending the mechanistic worldview.

\section{"Enlightened physicalism" of S. Kauffman: Introducing history}

Stuart A. Kauffman (1993, 2000), in contrast to concepts discussed above, fully recognizes the creativity and historicity of the physical realm. He started with modelling the dynamics of very complex systems, and showed that such systems have an inherent property of becoming self-organized and evolving. He therefore maintains that, in evolution, order (structure) will establish itself "for free", in spite of natural selection. From the mathematical world of models Kauffman made a decisive step to the physical world and attempted to find laws that would govern the evolution of a non-ergodic world. Kauffman's 
key concept is the autonomous agent, defined as an entity able of selfreproduction and of performing work cycles - i.e. canalising the flow of energy. An autonomous agent, in addition, can act on its own behalf in the sense that it evolves towards maximizing the efficiency of both these essential functions. Obviously, any living being belongs to the category of autonomous agents. What, however, should the properties of a physical system be for it to be able to act on its own behalf, i.e. to become an autonomous agent? Such a system must be able to increase its own organization.

But this is not the end of the story: autonomous agents are busy manipulating the surrounding world in order to maximize its diversity, co-constructing thereby a biosphere: "Biospheres persistently increase the diversity of what can happen next" (Kauffman 2000: 4). The configuration space of a biosphere cannot be defined in advance.

It does not, however, mean that biospheres are heading towards chaotic and unlimited diversity. Reaching out and making a living means making sensible choices from the space of possibilities created. We stress the word choices as an opposite to necessity imposed by natural selection: informed choice is unthinkable without the historical, experiential, hermeneutical dimension.

Kauffman tried to decipher lawful properties behind coconstructing biospheres, and he suggests the tentative 4th law" of thermodynamics. "As an average trend, biospheres and the universe create novelty and diversity as fast as they can manage to do so without destroying the accumulated propagating organization which is the basis and nexus from which further novelty is discovered and incorporated into propagating organization" (Kauffman 2000: 85).

Is this vitalism? If we take Driesch as a reference, the answer is no. There is, in Kauffman, no sign of the stiff physicalism so typical of Driesch. Quite the opposite is true: Kauffman focuses on creativity, spontaneity of the living. But how to name this quality "scientifically", formulate a concise theory, develop testable hypotheses and appropriate methods for their testing? In other words, how to define laws for non-ergodic evolving physical systems? In this sense Kauffman's views may be very close to those of the American semiotician C. S. Peirce, who hundred years before Kauffman stated that "natural laws are acquired habits". 


\section{Biosemiotics}

Biosemioticians maintain that, in contrast to inanimate matter which can be characterized by causal processes (action and reaction), the essence of the living is in semiosis, manipulation with symbols. Whereas "natural laws" represent generalizations about natural processes, helping to arrange the original heterogeneity under a small number of simple and homogeneous rules, the process of semiosis leads towards greater heterogeneity, elaboration, i.e. evolution (compare with the evolution of Kauffmanian biospheres above). Biosemiotics is an abstraction from the (causal) physical world, and focuses itself to a universe perfused with signs, where organic wholes participate in a never-ending interpretative process. The principal terms of biosemiotics are meaning and understanding, and the processes that create them. We consider crucial the following thesis, with all its reminiscences of vitalism or organicism:

The world is material, but all matter is organized into forms and these again can be further organized. There are qualitative differences between these organized forms. What exists are not just fundamental particles, energetic fields, and their organization: Reality has during its evolution become organized into characteristic primary levels (the physical, biological, psychical and social). Entities at higher levels possess emergent properties, some of which are ontologically irreducible to lower level properties. (Also called material pluralism or irreductive physicalism). Semiotic phenomena may be characteristic of some, but not necessarily all levels. (Emmeche 1997: 96)

We come to the view of an unfolding semiosphere (Hoffmeyer 1998) not incompatible with the visions of Kauffman or even those of Teilhard de Chardin (1956). All living beings participate, as experienced entities, in this process:

[...] we can say that when life, and thus natural selection, emerged inside the Earth system we had already passed beyond the secure sphere of physics into the sphere of communication and interpretation. In this sphere the dynamics of history (evolution) changed and began to become individualised, so that each little section of history became unique and henceforward no big formulas could be erected covering the whole process. Organic evolution is narrative rather than lawlike [...], and if quantification is wanted, it should be searched not at the level of genetics, but at the level of the constrained thermodynamic system framing organic evolution. (Hoffmeyer 1997: 365; our emphasis, A. M. and F. C.) 


\section{Anton Markoš, Fatima Cvrčková}

Semetic, instead of genetic, processes and interactions are considered the driving force of evolution. Emmeche (1997) even hopes that the biosemiotic effort will lead towards the integration of semiotics, biology and physics, and thus to the comprehension of emergence of new orders of complexity.

\section{Perspectives}

Examples above illustrated what were the problems biology has been struggling with for the past century. Biological field theory, structuralism, epigenetics, general systems theory, organicism and many other theories attempting the holistic or top-down approach in science, all remain somehow suspicious from the point of view of "true", prosperous, reductionist science. Biosemiotics, on the other hand, has completely left the realm of natural sciences.

The objective for the 21 st century is clear: either to conclude that some aspects of life's appearance simply cannot be subdued to the scrutiny of objectivist biology as we know it today, or to create a concise holistic theory of life, broadening thus the realm of biological science.

In the following part of our essay we shall attempt to outline two methodological (or epistemological) approaches that, to our opinion, may show some promise in relation to the second option mentioned: modular biology and hermeneutics.

\section{Modular biology: resurrecting classical genetics}

The term module can refer to a very heterogeneous set of entities. It can be applied to functional units in genomes - e.g. exons that can shuffle between the genes, thus increasing functional variability of encoded proteins (Patthy 1995). It can also represent autonomously developing units in ontogeny (Gilbert et al. 1996). However, here we shall focus mostly on the concept of modules as structural, regulatory, or functional units within cells (Hartwell et al. 1999), although some of the conclusions may apply also to the developmental, and even 
genomic, understanding of modules. What is common to all three conceptions mentioned is that modules serve as a kind of archetypal "scaffolding" for explication, i.e. forming some phenotypical trait. The scaffolding is relatively stable as to its internal relations. Its existence is a necessary condition for building the trait in question, but the trait itself cannot be derived from the existence of the scaffolding. What, then, comprises a module? Some of the Hartwellian modules are identical to previously recognized multiprotein complexes, such as the ribosome. Such entities could be, at least in principle, isolated in vitro and subjected to detailed chemical and physical analysis that would optimally lead to a 3-dimensional model of the corresponding molecular machinery. Others correspond to known regulatory or signal transduction pathways, such as protein kinase cascades and transcription regulation circuits involved in cell cycle regulation, hormone response and other cellular processes. In a general case, it is not spatial localization but functional relations what decides whether a particular molecule belongs to a particular module. In extreme cases, molecules belonging to the same module might never co-exist in the same cell! As a rule, modules are more likely to be discovered by the "old-fashioned" methodical apparatus of classical genetics than by high-tech 21 st century biochemistry alone, although they can, of course, be studied also by biochemical and molecular methods.

However, results of such studies, interesting as they undoubtedly are, do not contribute much to the understanding of relations between modules themselves. When studying these relations, we treat modules as black boxes, characterized only by their inputs and outputs. (For an alternative approach to the analysis of intracellular processes in terms of a network of relations - not between modules, but between molecules, see also Kanehisa 2000).

Indeed, if we aim towards understanding the basis of the extraordinary diversity and plasticity of life, we may that find the structure of the network of inter-modular relations matters more than the intra-modular processes. Modules themselves appear to be surprisingly conserved, comprising a kind of "basic toolbox" or a set of standardized blocks from which diverse bodies are built. What we observe as differences between modules in different lineages are more like dialects than different languages. Modules can become interconnected with other modules in a variety of ways, thus enabling 


\section{Anton Markoš, Fatima Cvrčková}

new combinations of intracellular regulations or ontogenetic pathways.

The conservative character of modules could be due to the necessity for horizontal communication between distant genealogical lines. This supposition is fully relevant at the level of the genetic code (note that the whole transcriptional and translational mechanism is a module par excellence) - especially in bacteria and archaea. Frequent and extensive genetic exchange across the bacterial world calls for a universal and conservative genetic language. To explain the conservation of modules by the necessity of horizontal transfer would, however, be quite challenging. The lineages represented by recent eukaryotic species tend to be well, if not hermetically, isolated. Horizontal exchange might have some importance immediately after speciation in so-called hybridization chains where great chunks of genetic material can move from species to species by interspecific hybridisation.

Another possible justification for a language of modules may be symbiosis: its existence will allow the partners to "understand" (or manipulate?) each other to differing extents. It is not that important whether the partners exchange their genetic material (mitochondria, chloroplasts) or not (lichens, ciliates, parasites). Such higher-order phenotypes require intimate interconnections between the regulatory systems of the constituting species. The establishment of multifarious symbiotic associations is typical in the biosphere, and the existence of a universal modular language undoubtedly makes it easier. It may even appear that symbioses (even in spite of the risk of parasitism) are advantageous in evolutionary terms, to the extent that there is a pressure to maintain the universal language in spite of genetic isolation.

Perhaps the most popular (and best known) example of a module, both in the Hartwellian and in the developmental sense, is the system of Hox genes. Chromosomal location of these genes is collinear with the body axis and their function corresponds to morphological modules which can be recognized on the body, such as segments (for a review see e.g. Davidson 2001). The products of homeotic genes, conserved throughout the metazoan kingdom, thus assign an "address" to the body structures. Incorrect addressing caused by incorrect functioning of the homeotic coding leads to so-called homeotic mutations, when structures appropriate to one type of segment appear 
at incorrect, ectopic sites. Many other regulatory modules are of such archetypal nature, for example systems specifying the dorsoventral axis in animals, the proximal-distal axis of appendages, the establishment of boundaries between body compartments, neurocranium, or left-right asymmetry. Similar archetypal regulations can be found also in plants.

Also another aspect of the project of modular biology, formulated by Hartwell et al. (1999), deserves attention in our context. The authors explicitly point to an obvious analogy between the processing and integration of multiple environmental and external signals by a (modular) cell on one hand - and analogous tasks performed by the metazoan nervous system on the other. As a result, they arrive to a rather shocking question: are there any modules that would correspond to a cellular equivalent of our nervous system?

If we accept this analogy and all conclusions it could lead to, we cannot but accept that, one day, cell biology may have to embrace the whole arsenal of methods, approaches and theories worked out in the long centuries of the study of diverse aspects of human nervous system. And there is no reason to stop at methods developed in the realm of neurobiology and related "nearly exact" sciences: biology has to be open to input from the humanities as well.

On the first glance, such an idea may appear preposterous, unacceptable and absurd. However, from a closer perspective the same objections could be raised against the previously sketched mechanistic models underlying most of traditional biology, as they are based on the rather immodest assumption that man-made devices are adequate models for understanding the world around and within ourselves.

\section{Hermeneutics of the living (or better by the living): Interpretation everywhere}

Taking the data of "standard" biology and re-interpreting them in the light of hermeneutics may be a good example of such an approach (Markoš 2002). In other words, we can view a living body as if it were a reader of texts, endowed with internal history (that of an individual and/or of a lineage). It masters a natural language, with understanding the meaning through word-by-word instructions as well as through cues, contexts, game of words, memory, communication with others, 


\section{Anton Markoš, Fatima Cvrčková}

etc. In short, the hermeneutic approach considers any living being as if endowed with abilities analogous to human consciousness.

As an example, take the gene - protein level of description. Here, genes play the role of dictionary entries, whereas proteins represent words that could appear in various grammatical forms, and, together with other proteins, constitute a plethora of predicates. The cell uses all this to weave a texture of temporal and spatial expressions, which reflect its context in the world.

A multicellular body can also be taken as an expression, where differentiated cells (including the extracellular matrix) are elements of syntactic and semantic relations. The dictionary would not be genes but whole modules (for example signalling cascades). In this metaphor, ontogeny is a species- (or genus-, phylum-, etc.) specific explication of a very old and conservative text shared by the greater part of, or even all, living beings. Like any explication, this too is subject to "cultural", historical shifts in course of evolution. A species-specific understanding of the genetic script is then an analogy to culture - specific understanding of, say, holy writ or the law codex. In this species-as-culture analogy, all the appearances of members of a species (morphology, behaviour, etc.) are results of habits acquired in course of historical contingencies. It follows that the causal bond "genetic inscription $\rightarrow$ body appearance" is far from being strict.

The deciphering of a code in DNA is often taken as a historical milestone: the existence of a digital code was, and is, felt as a warranty that all what is really important can, and indeed is, unequivocally written down in a string of symbols - bases. But there are two facets of the problem. First, it is true that digital information can be unequivocally copied within the realm of the digital. But it is often forgotten that it cannot be simply copied when transferred into a realm of the analogue, i.e. into the realm of bodily structures. This transition always requires interpretation (Gadamer 1989). The interpretation act is never a simple decoding as in case of transcription, translation, or transforming digital magnetic track into a text page on the screen (or a printer). Interpretation is always based in previous experience of the individual, species, lineage, an experience that goes back to the very beginning of life. Any interpretation is a historical singularity that will change the run of the world. To adapt the 
terminology of S. Kauffman, autonomous agents, by performing interpretation acts, bring the world into the adjacent possible.

In this respect, we are already entering the realm of ontology, the ontology of hermeneutic circle as laid out by M. Heidegger - or as outlined by modern physics in a somewhat different flavour (although non-physicists rarely appreciate this). However, even the physicists' world does not encompass the semiotic dimension yet. Adoption of the hermeneutic and semiotic methods by natural science would, hence, mean a decisive step towards biologisation of physics, centring sciences in biology - a bold parallel to the already accomplished biologisation of chemistry by development of organic chemistry and biochemistry.

\section{References}

Bertalanffy, Ludwig von 1960. Problems of Life. New York: Harper \& Brothers. Blackmoore, Susan 2000. The Meme Machine. Oxford: Oxford University Press. Brenner, Sidney 1997. Loose Ends. London: Current Biology Ltd.

Davidson, Eric H. 2001. Genomic Regulatory Systems: Development and Evolution. San Diego: Academic Press.

Dawkins, Richard 1989. The Selfish Gene. Oxford: Oxford University Press.

Driesch, Hans 1905. Der Vitalismus als Geschichte und als Lehre. Leipzig: J.A.Barth.

- 1914. The History and Theory of Vitalism. London: Macmillan \& Co.

- 1929. The Science and Philosophy of the Organism. London: A. \& C. Black.

Dyson, Freeman 1979. Disturbing the Universe. New York: Harper \& Row.

Emmeche, Claus 1997. The biosemiotics of emergent properties in a pluralist ontology. In: Taborsky, Edwina (ed.), Semiosis, Evolution, Energy: Towards a Reconceptualization of the Sign. Aachen: Shaker Verlag, 89-108.

Gadamer, Hans-Georg 1989. Truth and Method. London: Sheed \& Ward.

Gilbert, Scott F.; Opitz, John M.; Raff, Rudolph A. 1996. Resynthesizing evolutionary and developmental biology. Developmental Biology 173: 357-372.

Gilbert, Scott F.; Sarkar, Sahotra 2000. Embrancing complexity: Organicism for the 21st century. Developmental Dynamics 219: 1-9.

Hartwell, Leland H.; Hopfield John J.; Leibler, Stanislas; Murray, Andrew W. 1999. From molecular to modular cell biology. Nature 402: C47-C52

Havel, Ivan M. 1996. Scale dimensions on nature. International Journal of General Systems 24: 295-324.

Hess, Benno; Mikhailov, Alexander 1995. Microscopic self-organization in living cells: A study of time matching. Journal of Theoretical Biology 176: 181-184. 


\section{Anton Markoš, Fatima Cvrčková}

- 1996. Transition from molecular chaos to coherent spiking of enzymic reactions in small spatial volumes. Biophysical Chemistry 58: 365-368.

Ho, Mae-Wan 1993. The Rainbow and the Worm. Singapore: World Scientific.

- 1994. Liquid crystalline mesophases in living organisms. In: Ho, Mae-Wan; Popp, Fritz-Albert; Warnke, Ulrich (eds.), Bioelectrodynamics and Biocommunication. Singapore: World Scientific, 213-227.

Hoffmeyer, Jesper 1997. Biosemiotics: Towards a new synthesis in biology. European Journal for Semiotic Studies 9(2): 355-376.

- 1998. The unfolding semiosphere. In: Vijver, Gertrudis Van de; Salthe, Stanley N.; Delpos, Manuela (eds.), Evolutionary Systems: Biological and Epistemiological Perspectives on Selection and Self-organization. Dodrecht: Kluwer, 281-293.

Kanehisa, Minoru 2000. Post-genome Informatics. Oxford: Oxford University Press.

Kauffman, Stuart A. 1993. The Origins of Order: Self-organization and Selection in Evolution. Oxford: Oxford University Press.

- 2000. Investigations. Oxford: Oxford University Press.

Markoš, Anton (2002, in print). Readers of the Book of Life: Contextualizing Evolutionary and Developmental Biology. Oxford: Oxford University Press.

Monod, Jacques 1979. Chance and Necessity. Glasgow: Collins/Fount.

Patthy, László 1995. Protein Evolution by Exon-shuffling. Heidelberg: Springer.

Pokorný, Jiří (ed.) 1995. Biophysical Aspects of Coherence. Special issue of Neural Network World 5(5).

Teilhard de Chardin, Pierre 1956. La place de l'homme dans la nature: Le groupe zoologique humain. Paris: Seuil.

Webster, Gerry; Goodwin, Brian C. 1996. Form and Transformation: Generative and Relational Principles in Biology. Cambridge: Cambridge University Press.

Wilson, Edward O. 1998. Consilience: The Unity of Knowledge. New York: Alfred A. Knopf.

\section{Назад к науке о жизни}

Статья предлагает обзор эпистемологических и онтологических подходов, оставивших свой след в биологии XX века. Общее для всех них стремление - соединить биологию и точные науки. Попытки эти не удались и им суждено провалиться и в будущем, пока критерии, на основании которых определяется статус науки, не станут биологически ориентированными. Это означало бы расширение классической сферы наук о природе, путем присоединяя к ним хотя бы части понятийного аппарата "гуманитарных наук". Предлагаем три взаимодополняющих друг друга возможных кандидата для дальнейшего развития в этом направлении: модулярная биология, герменевтика живого и семиотические дисциплины. 


\section{Tagasi eluteaduse juurde}

Artikkel annab ülevaate epistemoloogilistest ja ontoloogilistest lähenemisviisidest, mis on jätnud jälje 20. sajandi bioloogiasse. Ühine motiiv enamikule neist on püüe liita bioloogia ühte täppisteadustega. Seesugused katsed on siiski ebaõnnestunud, ja ebaõnnestuvad ka tulevikus, kuni kriteeriume, mille alusel määratletakse, mis on teadus, ei ole muudetud bioloogiakeskseks. See tähendab klassikaliste loodusteaduste sfääri laiendamist, ühendades nendega vähemalt osa "humanitaarteaduste" mõistestikust. Esitame kolm vastastikku üksteist täiendavat kandidaati selle suuna edasiseks arendamiseks: modulaarne bioloogia, elusa hermeneutika ja semiootilised distsipliinid. 